\title{
COMMON GRACKLES ANTING WITH MARIGOLD FLOWERS
}

ROBERT W. NERO, Box 14, 1495 St. James Street, Winnipeg, Manitoba, R3H OW9, and DAVID R.M. HATCH, 876 Elizabeth Road, Winnipeg, Manitoba. R2J 1 A8

"Anting" is a puzzling activity of birds in which a bird treats its feathers with ants or substitute materials. It was first reported by Audubon and has been a matter of interest to ornithologists ever since. The behaviour of anting is stereotyped and involves vigorous movements to apply ants and a wide variety of other items to ventral parts of its body, particulary the underside of the wings and tail. ${ }^{4}$ In a comprehensive report in 1957 , Whitaker listed 148 species of birds which had been observed anting. ${ }^{5}$

A recent popular book devotes an entire chapter to anting and "related antics."' Although plant materials, e.g., fruits, fresh walnut husks, foliages, raw onion and gum of grass-tree have been used for anting, there are apparently no published observations of birds anting with flowers. ${ }^{5}$

It is thus with some surprise that we have learned that Common Grackles have evidently been anting with marigold flowers in city yards in Winnipeg for several years. This was first brought to our attention by Cathy Kaminski, who reported that from mid-July to 21 July 1983 , she observed some black birds (probably grackles) regularly performing a strange ritual in her backyard. One at a time, each of about six birds flew down by her flowerbed and plucked off a yellow marigold. The birds then vigorously rubbed the flower against its wings and breast, wherever it could reach, until flower petals were torn loose. Then the bird would pluck another flower and repeat the process, going through three or four flowers before flying away. UsualIy this took place before 8:00 a.m. The bird would go through some peculiar con- tortions while rubbing the flower into its plumage. Nero visisted the Kaminski yard on several occasions after getting this report, but failed to see any birds in the vicinity. Little heaps of yellow petals were seen in various places on the lawn, lending support of Kaminski's report.

Following the publication of a description of Kaminski's observations in a newspaper column, several additional reports of a similar nature were received by telephone and mail from 12 to 15 August, 1983. ${ }^{3}$ David Bradley wrote: "Early one mid-July morning I looked out my window before six a.m. and noticed about six or eight adult and young grackles pulling apart marigolds. Two or three of them just seemed to scatter the petals around but two or three others made exact moves of putting a beakful of petals under each wing and rubbing them on their breasts. One adult male made two or three such applications."

Mrs. Gerry Zborowsky wrote: "I have had the same trouble for the past couple of years. My neighbors and I thought it was our poodle breaking off all the marigold flowers and tearing them off. I have since found out that it is the 'Grackles' . . . We have had a lot of them around here for the past few years."

Enid and Doug Bond stated: "The birds around here eating the tops off the marigolds are the Common Grackle. Our neighbor, Edna Gowanlock, put in a border of the small marigolds. Doug . . . had watched [grackles] doing their antics with the blossoms. They were still at it this morning. There are a very few flowers left. My other neighbor, Mrs. Doris Wrigley ... put in marigolds, and was 


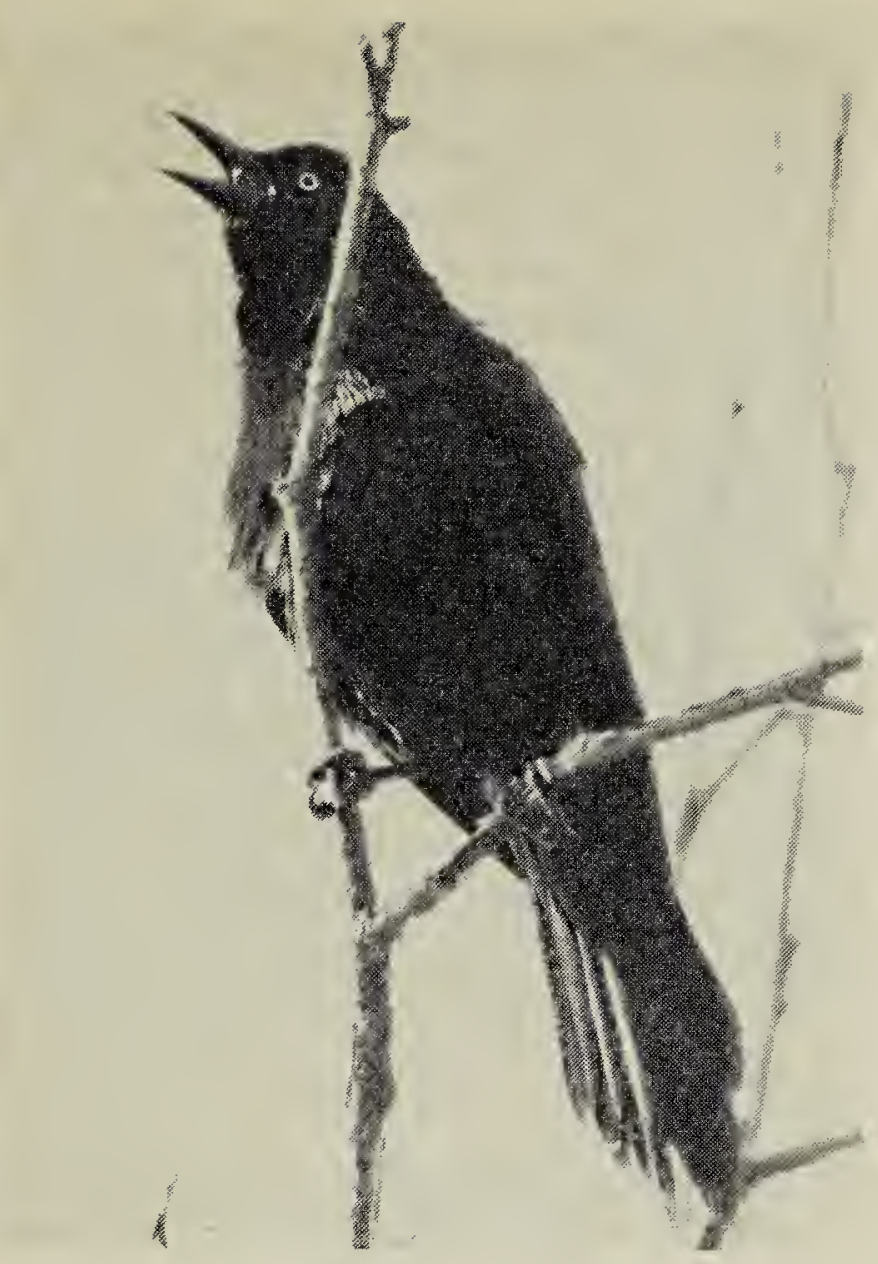

Common Grackle

Four Winds Prairie Photography

quite annoyed to see the "Darn Blackbirds' eating all her flowers."

Robert Parsons wrote as follows: "I have seen Common Grackles indulging in the same behaviour [as reported by Mrs. Kaminski] ... In the summer of 1979 our front flowerbeds were planted with marigolds . . . In the middle of June we began to notice that quite a considerable amount of the marigolds in the flowerbed adjacent to the lawn had lost their flowers. The blossoms were visible at the base of the plants [and were] all pulled apart ... Presently the other flowerbed began to be attacked as well. We probably would have gone on suspecting rabbits had it not been for my observations one morning ... Not too long after the sun rose a flock of about 5 or 10 grackles landed in our now defunct weeping birch tree ... after a minute or two one bird flew down to the lawn and strutted towards the marigolds (the others followed it) and tore off a flower, pecked at it until he had broken it up and began rubbing the petals through his feathers particularly those on his breast and wings. Presently they were all doing this and began acting as if they were drunk, seemingly unable to balance as they swayed from side to side. Finally, however, they 'recovered' and flew away. At the end of the nesting season, the grackles abandon our area. This is usually at the end of July or beginning of August. At this time the attacks on our marigolds ceased. The following summer we had marigolds in our flowerbeds again, and again they were attacked. I have never seen the grackles at the marigolds since (it's not my favourite time of day!) but I assume that they're responsible. Our marigolds (both years) were not yellow like Mrs. Kaminski's but were two-toned orange and reddish-brown. On one occasion a rose was found in a similar condition. It was immediately adjacent to the marigolds and was a very similar color and we assume a bird mistook it for a marigold, as no other colored roses were attacked ... This year we have virtually no marigolds ... and have observed no damage ... Although one of my next door neighbors has had the same problem; the problem is not terribly widespread and many of our other neighbors have marigolds without problems."

Charles Rebbeck noted: "Around July 23 I found all 30 of our miniature marigolds had been deflowered with the blooms littering the flowerbed ..." Mrs. Doris Yates reported: "Both myself and my next door neighbor, Mrs. Donna Dickson, have stopped trying to grow these flowers ... year after year ... marigolds would just be nicely into full bloom when along would come as many as $20 \ldots$ grackles and within 15 to 20 minutes, all, or most of the flowers would be destroyed. These birds were not seen 'anting' but could have done so as we did not always see them until the damage was done." Again Brenda E.S Brereton noted: "For a number of years now, I have been bothered by grackles pulling off the marigold flowers." And Ann Lan- 
caster added: "My neighbor has marigolds in her border that have been beheaded a few times this year by a flock of grackles. I observed them myself on one occasion, picking ferociously and scattering the flowers on the ground." Doris Cortilet reported that grackles had been coming to their yard for years, dissecting marigold flowers to get the centers to feed their young. She said that she "has never seen them apply flowers to their wings." Although this last report suggests a different reason for grackles using marigold flowers, the evidence is strong that anting behaviour is a primary factor causing grackles to seek out these plants.

Marigolds (chiefly genus Tagetes) are among a group of flowers that contain pyrethrum, a natural insect repellant. Horticulturists have long been aware that parasitic worms called nematodes disappear from the soil in which marigolds have grown. ${ }^{1}$ Mrs. Doris Cortilet added that she "grew marigolds to protect tomatoes and other vegetables from insects." And David Bradley added that: "Having read previously in a book about gardening secrets that marigolds contain a natural pyrethrum I thought that these [grackles anting with marigolds] were very smart birds. I thought that perhaps the marigold odor or oil might discourage lice or other parasites."

The above astute comment is close to what ornithologists have concluded is one possible basis for anting behaviour. Some forms of marigolds have a strong odor - others lack any odor, but since most birds have a poor sense of smell, this is probably not the stimulus source. Marigold petals, as noted by Nero when visiting Kaminski's yard, have a strong, bitter flavour, and it is more likely that this is the stimulus source releasing the anting behavior. That Common Grackles respond to strongly-flavoured substances has been reported in the literature. In Milwaukee, a flock of about 20 grackles was seen coming daily to a vegatable garden. "It was discovered that the birds were anting with partly evaporated mothballs put out to discourage rabbits."'2

We would like to thank Jean Bancroft for drawing our attention to the book by J.V. Dennis, and thank all of the informants for sharing their observations.

1 CROCKETT, J.V. 1971. Annuals. Time-Life Books, New York. 176 pp.

${ }^{2}$ DENNIS, J.V. 1981. Beyond the bird feeder: the habits and behavior of feeding station birds when they are not at your feeder. Alfred A. Knopf, New York. 244 pp.

${ }^{3} \mathrm{HATCH}$, D. 1983. "Chickadee Notes", Winnipeg Free Press, August 12, 1983.

${ }^{4}$ WELTY, J.C. 1962. The life of birds. W.B. Saunders Co., Philadelphia. 546 pp.

${ }^{5}$ WHITAKER, L.M. 1957. A resume of anting, with behavior reference to a captive Orchard Oriole. Wilson Bull. 69:195-262.

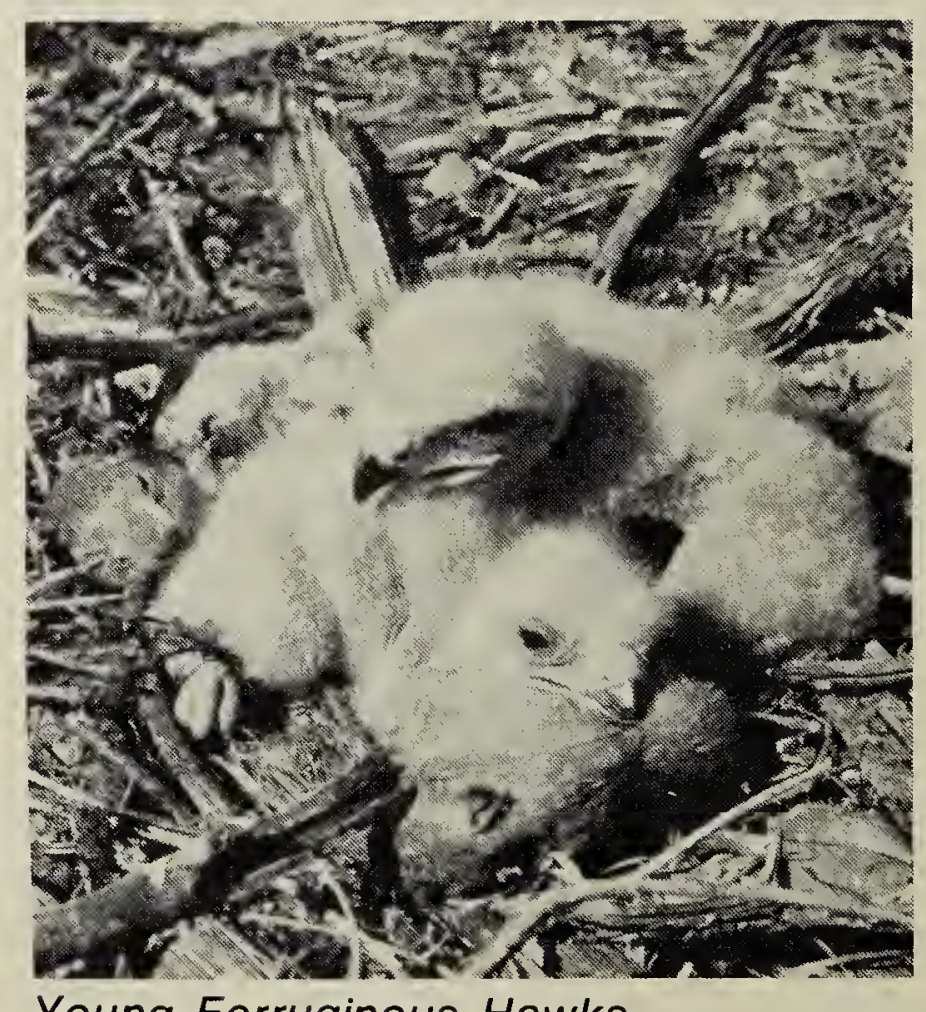

Young Ferruginous Hawks

Gary W. Seib 